\title{
THE EFFORTS TO OVERCOME THE DIFFICULTIES OF LEARNING ARABIC IN MTs. YASRIB LAPAJUNG BOARDING SCHOOL
}

\author{
Syamsudar \\ STAI Al-Gazali Soppeng \\ Jln Merdeka No 85 Watansoppeng 90812 South Sulawesi \\ Email: syamsudar@gmail.com
}

\begin{abstract}
This study aimed: 1) to describe the learning process in MTs. Yasrib Lapajung Boarding School, 2) To reveal the kind of difficulties in learning Arabic in MTs. Yasrib Lapajung Boarding School, 4) To describe the efforts done by Arabic teachers in overcoming the difficulties of learning Arabic in MTs. Yasrib Lapajung Boarding School. This research was descriptive qualitative by analyzing and describing the data in an objective and detailed manner to obtain accurate results. The data sources of this study were from the headmaster, Arabic teachers, and the students of MTs. Yasrib Lapajung Boarding School as informants. The technique of data collection was done by conducting interview, observation, and documentation. Data processing technique and qualitative analysis used three stages, namely: 1) data reduction, 2) data display, and 3) conclusion. The results showed that; first, the process of learning Arabic in MTs. Yasrib Lapajung Boarding School was divided into three parts, they were learning plan, implementation, and evaluation. Second, the students' difficulties that emerged in learning Arabic, namely: istima' (listening), kalam (speaking), qira'ah (reading), and kitabah (writing). Third, to overcome the learning difficulties that existed in learning Arabic related to difficulties in aspects of language skills, the teacher asked the students to memorize mufradat (vocabulary) and translate a sentence, to write Arabic by dictation (imla'), and to practice conversation so that the students were accustomed in
\end{abstract}


speaking Arabic, the teacher also fostered the students' motivation and interest, and held extracurricular activities.

Key words: Learning difficulties, MTs. Yasrib Lapajung Boarding School

\section{Introduction}

Arabic is a subject aims to encourage, guide, develope and foster the abilities and positive attitude towards Arabic both receptively and productively. The ability to speak Arabic and the positive attitude towards Arabic are very important to understand the sources of Islamic teachings, namely the holy Koran and Hadith, as well as Arabic books, especially for the students of MTs. Yasrib Lapajung which is a formal educational institution that is located neighborhood of Islamic Boarding Schools.

The development of learning Arabic in MTs. Yasrib Lapajung Boarding School was still classified less than optimal after the researcher saw the results of the students' language skills when studying Arabic subject. In this case, the researcher found that the variety of backgrounds caused Arabic language skills in the class were relatively low, including different educational backgrounds, lack of motivation, lack of vocabulary and understanding of Arabic structure. The most prominent problem found by the researcher was the lack of the students' ability to read Arabic text and to comprehend the contents of the text. Difficulty in reading Arabic text for the students not only in terms of spelling the words, sentences, and paragraphs, but also 
understanding the meaning of the sentences, whether the Arabic text has Tashkil (diacritics) or not. Hence, reading Arabic text is one of the difficulties in teaching and learning Arabic. The ability to read Arabic text fluently influences the success of teaching and learning activities, especially listening (istima'), speaking (kalam), reading (qira'ah) and writing (kitabab).

Based on these problems, there were several facts which became the most important foundation of this study. Problems faced by the students such as qira'ah (reading) and mubadasah (conversation) sometimes were not realized by the teachers.

The researcher was interested to conduct a study related learning difficulties of Arabic based on the description above, especially to describe the teaching and learning process, to find out the factors caused the students' difficulties in reading Arabic text, and how the teachers solve those problems in MTs. Yasrib Lapajung Boarding School.

This study was field research which was conducted by observing the reality of social life. ${ }^{1}$ It was a qualitative descriptive reasearch that intended to understand the phenomenon of the research subjects' experience and to get descriptive data in written or verbal form. ${ }^{2}$ In qualitative research, data collection is carried out under natural

${ }^{1}$ Suharsimi Arikunto, Prosedur Penelitian: Suatu Pendekatan Praktek (Edition. XIII; Jakarta: Rineka Cipta, 2006), p. 9.

${ }^{2}$ Lexy J. Moleong, Metode Penelitian Kualitatif (Edition. XXVI; Bandung, PT. Remaja Rosdakarya, 2009), p. 6. 
conditions by using several methods, namely: (1) interview; (2) observation; and (3) documentation. ${ }^{3}$ Based on the main problems, types, characteristics, and sources of this research, data collection were done through observation, interview, and documentation for further analysis.

\section{Results and Discussion}

General Description of MTs. Yastib Lapajung Boarding School

Yasrib Islamic boarding school was established since 1982 which was allocated \pm 9 ha in the land area of Soppeng District Government located in Lapajung Village, Lalabata District, Soppeng. Yasrib Lapajung Islamic Boarding School is a business unit of the Islamic Foundation in Beowe Soppeng.

Learning Process of Arabic Subject in MTs. Yasrib Lapajung Boarding School

The Government Regulation Number 19 in 2005 concerning one of the National Education Standards that must be developed is the process. It is a national education standard relating to the implementation of learning in educational units to achieve alumni's competence. The standard process consists of three stages namely learning plan, implementation, and evaluation. Likewise in the process of learning Arabic at MTs. Yasrib Lapajung Boarding School also goes through these three stages.

p. 309 .

${ }^{3}$ Sugiyono, Metode Penelitian Kombinasi (Mixed Methods), 
After doing documentation, observation and interview to the various parties related to this study, the researcher described the implementation of teaching and learning Arabic in MTs. Yasrib Lapajung Boarding School as follow:

\section{Learning Plan}

The planning stage was the initial stage that must be done by the teacher in each learning process. The students would participate actively in learning activities if the teacher had good preparation so that the teaching and learning process could be more effective and efficient.

MTs. Yasrib Lapajung Boarding School conducted learning through two activities, namely intracurricular and extracurricular. The intracurricular activities were carried out during class hours either in the morning or afternoon, while extracurricular were held in the afternoon.

The Arabic teachers prepared learning plan before teaching and learning process. They made lesson plan at the beginning of each school year or new semester. The important things that should be considered in learning plan were the learning objectives and the curriculum used.

a. Learning objectives

In general, the purpose of learning Arabic in MTs. Yasrib Lapajung Boarding School, as well as other educational institutions, was the students had linguistic competencies or the abilities in listening, speaking, reading, and writing Arabic.

b. Curriculum 
Teaching and learning Arabic in MTs. Yasrib Lapajung Boarding School generally had fulfilled the language curriculum requirements because the material and learning process had set the competencies related to the four language skills, namely listening, reading, speaking and writing. In addition, the implementation of learning methods were quite varied.

\section{Implementation}

In the implementation stage, the teacher carried out the teaching and learning interaction activities based on the lesson plan. The learning materials were adjusted with a sequence that has been systematically prepared in the planning stage.

Arabic teachers at MTs. Yasrib Lapajung Boarding School divided learning activities into three parts namely introduction, core and closing activities.

In the process of teaching Arabic, the teachers of MTs. Yasrib Lapajung Boarding School were not only focused on one but several methods. The methods used were lecture, question and answer, group discussion, and others.

3. Evaluation

Evaluation of learning outcomes aimed to assess the effectiveness and efficiency of the teaching and learning process for the improvement and development of the program and its implementation. Evaluation was carried out by the teachers as an integral part of the learning itself.

Evaluation form of MTs. Yasrib Lapajung Boarding School were test and non-test. Test was given in the form of 
written or verbal questions in the middle and the end of the semester. Whereas the non-test was carried out during the Arabic teaching and learning process by using several aspects of assessment.

Evaluation was very important to measure the level of the students' understanding and also to know the extent of the teachers' success in teaching the materials to the students.

\section{Difficulties of Learning Arabic in MTs. Yasrib Lapajung Boarding School}

To describe objectively the abilities and difficulties of learning Arabic in MTs. Yasrib Lapajung Boarding School, the researcher used the observation and interview guidelines. After doing observation, interview and taking documentation, the result showed that the students in MTs. Yasrib Lapajung Boarding School had learning difficulties in various realms of Arabic subject which has been set in the National Curriculum for teaching and learning Arabic, as follow:

\section{Cognitive}

Based on the results from the observation and interview, the researcher found that learning difficulties related to the cognitive realms as follow:

a. Listening difficulty

Listening or istima' was an important learning experience for the students and should get great attention because listening was one of the important skills in learning Arabic. 
One of the causes of listening difficulties in MTs. Yasrib Lapajung Boarding School was the students less accustomed to listen Arabic and also could not differentiate the letters which had the similiarity in pronunciation. When trying to interact in the classroom using Arabic, the students sometimes were asked by the teacher to repeat their sentences because it was unclear.

b. Speaking difficulty

'The students' ability to speak was not a stand-alone skill but interrelated with other abilities, such as vocabulary, listening, reading, and writing skills. These four aspects of learning Arabic could not be separated. Thus, the ability to speak must be started from listening, pronuncing and mastering vocabulary so that the students could express their thoughts. $^{4}$

Based on the observation result of field research, it was found that the students who got difficulties in istima' (listening) also gained problems in kalam (speaking). When the researcher observed the teaching and learning process, the Arabic teacher sometimes talked or asked the students a question but they could not answer fluently or gave respon in their native language (Bahasa).

b. Reading difficulty

Qira'ah or reading skill was one of the important aspects of learning Arabic to explore knowledge through reading Arabic text. It sometimes had no Tashkil (diacritics)

4 Ahmad Fuad Efendi, Metodologi Pengajaran Bahasa Arab (Malang: Misykat, 2005), p. 112-113. 
to practise the students' reading ability which could not be separated from syntax and morphology form (nabwu and sharaf), adequated vocabulary, reading habit and meaning comprehension.

The objectives to be achieved from reading activity were the students were able to read Arabic texts fluently, able to translate and able to understand well. ${ }^{5}$ Therefore, if there were students who were not fluent in reading, unable to translate, and did not understand well, it meant that the students had difficulties in their qira'ah abilities.

2. Affective

The affective realm dealed with attitudes and values. Affective included the nature of behavior such as feelings, interests, attitudes, emotions, and values. Some experts said that a person's attitude could be predicted if he/she has a high level of cognitive power.

a. Interest

The students who had interest of the subject tended to care the material learned. In this case, the teachers should try to get the students' interest and encourage them to master the subject so that the teaching and learning process run conducively and they could get good learning achievement.

Students who had learning interest participated actively, studied hard, looked persistent, did not give up, and diligently read several books to improve their knowledge to overcome their learning problem. In the other hand, those

${ }^{5}$ Suja'i, Inovasi Pembelajaran, Bahasa Arab (Jawa Timur: Walisongo Press, 2008), p. 21. 
who had no interest seemed indifferent, easily discouraged, did not focuse on the lesson, disturbed the learning process, often left the class that caused learning difficulties.

The students of MTs. Yasrib Lapajung Boarding School thought that Arabic subject was a boring lesson because of the lack of knowledge of Arabic meaning. This problem affected the students' interest in Arabic lessons so that they found difficulties in learning Arabic.

The students' interest in learning Arabic at of MTs. Yasrib Lapajung Boarding School was still lack. There were no motivation and attention to speak Arabic among the students as daily conversation.

b. Attitude

The students' attitude to accept lessons was a reflection of their interest to learn especially in Arabic lessons. The students who had an interest in Arabic show a positive attitude when learning Arabic, whereas those who had no interest tended to show less attitude when learning.

Learning difficulties faced by the studets of MTs. Yasrib Lapajung Boarding School in learning Arabic were not without any reasons. Various factors influenced the problems as follow:

a. Internal Factors

In learning activities, the students sometimes faced difficulties or problems in learning especially in Arabic subject. There were several factors that caused the students got difficulties in learning. These factors are as follow:

1) The students' background 
The heterogeneous background of the students made their understanding of learning Arabic also different.

The students of MTs. Yasrib Lapajung Boarding School graduated from elementary schools which incidentally did not have basic knowledge of Arabic excepted from the holy Koran and prayers. This caused the students had difficulties dealing with Arabic in class.

2) Intelligence

Intelligence was an innate ability that could be used to adjust new needs with the goals by using thinking tools. The intelligence of each students of MTs. Yasrib Lapajung Boarding School were different, some had high, medium and low intelligence.

b. External factors

1) Teacher

The teacher was an educator who had responsiblity in teaching. To be able to carry out their duties and responsibilities, an Arabic teacher must have a number of competencies or master a number of knowledge, attitudes, and skills related to their field of work to teach Arabic.

Based on the observations, it could be seen that the teachers spoke Arabic fluently but they did not fully use Arabic when teaching the lesson. They used bilingual language because several students did not understand the material taught by the teacher. This happened because of the students' heterogeneous abilities and different educational background. The teachers also did not speak Arabic in daily 
conversation so that the students had no role model to encourage them to speak Arabic.

Based on the observation result, during the learning process the Arabic teacher always tried to provide feedback and opportunity to the students asking question if they did not understood. But the students sometimes just kept silent and did not ask anything.

2) Family

The students' lack to master Arabic both active and passive abilities was not only due to the fault of the Arabic teachers but the family also had influences. Basically the students' parents in MTs. Yasrib Lapajung Boarding School were Muslim but they were not accostumed with Arabic. They only used Arabic when praying and readig the holy Koran so that their knowledge toward Arabic was limited.

\section{The Teachers' efforts to overcome Arabic Learning difficulties in MTs. Yastib Lapajung Boarding School}

In order to achieve learning objectives, the teachers did various efforts to get the students' enthusiasm toward learning Arabic. Every educational institution who wanted to develop the students' quality must certainly take concrete efforts to get that goals. In this discussion, the researcher described the efforts done by the Arabic teachers in MTs. Yasrib Lapajung Boarding School toward the students in overcoming the Arabic learning difficulties.

There were several ways that the teachers did to solve the Arabic learning difficulties as follow: 


\section{Cognitive Difficulties}

a. Ask the students to memorize mufradat and its meaning

Memorizing mufradat (vocabulary) aimed to improve the students' Arabic vocabulary and translating word by word made them know the meaning of that Arabic words. Besides, the teachers also taught the correct pronunciation to the students. Thus, the students knew several Arabic words and its meaning then able to pronunce it correctly.

After that, the students practiced to speak Arabic without using the correct Arabic grammar to make them comfortable and confidence talking in Arabic. Furthermore, the teacher fostered the students' vocabulary through forming sentences in daily conversation which could develop the other language skills.

b. Train the students to write Arabic with imla'

The students' activity in writing Arabic by dictation was expected to develop their writing Arabic pattern by listening the words than just draw the similiar letters that they seen. When the students accostumed to write Arabic, they would not be bored to learn Arabic later.

\section{Affective Difficulties}

Giving motivation related to the needs, motives and goals, greatly influenced teaching and learning activities because it directed the students' actions in learning process. Thus, to improve the students' interest the teachers were required to motivate them. Arabic teachers as motivators had duty to encourage the students to adapt actively and creatively in learning environment. The teachers should give suggestion 
to the students to learn Arabic, both in class hours and their free time.

However, the students must had enthusiasm in learning Arabic, willingness and attention could come from themselves. Therefore, the enthusiasm that existed from the students was the main key to deal with all difficulties in learning Arabic.

The teacher fostered the students' motivation by telling them about the successes achieved by the teachers and alumni from that school in variuos level of competitions related to Arabic so the students did not thought learning Arabic as a burden. They also explained that learning Arabic is important for them in the current era of globalization, both for communication and for worship.

In addition, the headmaster and the teachers of MTs. Yasrib Lapajung Boarding School continued to overcome the Arabic learning difficulties of the students through other efforts as follow:

a. Implementing updated method appropriate to the learning objective

The method was the strategy used by the teacher to convey the subject matter to the students so that the goals to be achieved in the teaching and learning process could be realized. Therefore, with the certain method used by the teacher, the material conveyed to the students could be easily accepted.

A teacher could choose the appropriate teaching method. A school considered successful in teaching and 
learning process if the formulated goals in the curriculum can be achieved within a predetermined period of time. Therefore, achieving goals was determined by the implemented method. The application of a method in each field of teaching must concern and consider the possibilities to obtain standard quality and effective of a method. If it was not, the teaching process would not only be hampered but also the teaching goals might fail.

Another thing that needed to be considered by the teachers in choosing and determining a method was the students. Every one of them had different abilities, intelligence and different character. A teacher must have wisdom in choosing and establishing a teaching method to bring out the talent, interest and concern of the students in learning Arabic.

b. Cooperating with the students' parents

Parents are the teachers at home so they should concern to their children's learning development. For this reason, parents need to help the teachers to educate their children.

The teachers of MTs. Yasrib Lapajung Boarding School collaborated with the students' parents by reporting their learning achievement that must be signed by their parents so that they would care to the improvement of learning Arabic.

c. Holding Arabic extracurricular activities

In extracurricular activities, the students must participate in additional program at the end of the semester. 
In the Arabic camp, there are two types of guest coach brought from Islamic boarding school of Rahmatul Asri Enrekang, they were teacher as coach and several students as the peer tentor.

During Arabic camp, the teachers only watched over the students to participate seriously to that program. The teachers did not interfere the Arabic camp, all of the activities handled by the guest coaches for the successfull of the program. Through Arabic Camp and the assistance of Rahmatul Asri Islamic, the students were also expected to be motivated to learn Arabic and to be like their peer coaches.

\section{Conclusion}

1. The process of learning Arabic at MTs. Yasrib Lapajung Boarding School was divided into three parts, namely learning plan, implementation, and evaluation. The learning plan was the stage where the teachers prepared everything needed in teaching so that the teaching and learning process could be more effective and efficient. In the implementation stage, the teacher carried out the teaching and learning interaction activities based on the lesson plan. The learning materials were adjusted with a sequence that has been systematically prepared in the planning stage.

Evaluation form of MTs. Yasrib Lapajung Boarding School were test and non-test. Test was given in the form of written or verbal questions in the middle and the end of the semester. Whereas the non-test was carried 
out during the Arabic teaching and learning process by using several aspects of assessment.

2. The Arabic learning difficulties faced by the students of MTs. Yasrib Lapajung Boarding School were: difficulties in istima', kalam, qira'ah, and kitabah. The factors divided into two causes, namely: internal factor included the mayority of the students of MTs. Yasrib Lapajung Boarding School who graduated from elementary schools which had no Arabic subject thought it was difficult and not interested. The students' intelligence and interest in learning Arabic especially using Arabic as daily conversation at school was very low.

The external factors was the teaching method implemented by the Arabic teacher was not interest and approppriate with the students' learning style which caused the teaching and leaning objectives could not be achieved. The lack of Arabic books and the knowledge relating Arabic of the students' parents made them got difficulties studying Arabic at home.

3. There were several ways that the teachers did to solve the Arabic learning difficulties, they were: Asking the students to memorize mufradat and its meaning and training the students to write Arabic by dictation or imla ', giving them daily conversation so that they were accostumed to speak Arabic, encouraging and motivating the students to study Arabic and to avoid negative thinking that Arabic was a burden, explaining that Arabic was important for doing communication in 
this globalization era and in worshipping, implementing the approppriate method considering the students' intelligence, ability, and character's learning style, cooperating with the students' parents to attend the school meeting to discuss the students' difficulties in learning and to tell them care in students' learning improvement, and holding Arabic extracurricular programs such as Arabic camp.

\section{REFERENCES}

Suharsimi Arikunto, Prosedur Penelitian: Suatu Pendekatan Praktek (Edition. XIII; Jakarta: Rineka Cipta, 2006), p. 9.

Lexy J. Moleong, Metode Penelitian Kualitatif (Edition. XXVI;

Bandung, PT. Remaja Rosdakarya, 2009), p. 6.

Sugiyono. Metode Penelitian Kombinasi (Mixed Methods). Edition. III; Bandung; Alfabeta, 2012.

Effendy, Ahmad Fuad. Metode Pengajaran Bahasa Arab. Edition. III; Malang: Misykat, 2005.

Suja'i. Inovasi Pembelajaran Bahasa Arab. Jawa Timur: Walisongo Press, 2008. 